\title{
PENERAPAN STUDENT CENTERED LEARNING (SCL) MELALUI METODE MNEMONIK DENGAN TEKNIK ASOSIASI PADA MATA KULIAH KANJI DASAR
}

\author{
Linna Meilia Rasiban \\ Jurusan Pendidikan Bahasa Jepang FPBS UPI \\ Korespondensi: Jln. Dr. Setiabudhi 229 Bandung 40154 \\ Pos-el: $\underline{\text { linnameilia@upi.edu }}$
}

\begin{abstract}
Abstrak
Penerapan student centered learning (SCL) melalui metode Mnemonik dengan teknik asosiasi pada mata kuliah kanji dasar (Shokyu Hyouki). Tujuan dari penelitian ini adalah untuk mengetahui keefektifan media pembelajaran serta pengaruhnya dalam meningkatkan kemampuan mahasiswa dalam pembelajaran kanji dasar Kanji merupakan salah satu unsur penting dalam mempelajari bahasa Jepang, tapi sekaligus hal yang dianggap sulit dipelajari oleh pembelajar bahasa Jepang. Selama ini dalam mengajarkan kanji sebagian besar menggunakan metode ceramah dengan media yang berpusat pada pengajar (teacher center). Penelitian ini untuk menjawab permasalahan mengenai kesulitan mahasiswa dalam hal menghafal makna kanji dengan menitikberatkan pada perbaikan media ajar yang selama ini telah dilakukan. Metode penelitian yang digunakan adalah metode eksperimen. Hasil penelitian menunjukkan bahwa media CD interaktif dapat membantu mahasiswa dalam menghafal makna kanji terutama pada saat mengerjakan soal ujian.
\end{abstract}

Kata kunci : SCL, metode mnemonik, teknik asosiasi, kanji dasar

Abstract

Application of student centered learning (SCL) through mnemonics method and associated technique in basic Kanji (Shokyu Hyouki). The purpose of this study was to determine the effectiveness of instructional media and its influence in improving students' ability in learning basic kanji. Kanji is one important element in studying the Japanese language, but at the same time, it is the most difficult by Japanese learners. So far, in most of the kanji taught using lecture method with media-centered teaching (teacher center). This research concerns about student difficulties in memorizing kanji meaning with emphasis on the improvement of instructional media that had been done. The research method used was experimental method. Based on the results of this study concluded that sufficient media interactive CD helps students to memorize kanji meaning, especially when working on the exam.

Keywords: SCL, mnemonics method,associated technique,basic kanji. 


\section{PENDAHULUAN}

Kanji merupakan salah satu unsur penting dalam mempelajari bahasa Jepang, tapi sekaligus hal yang paling sulit dan ditakuti oleh pembelajar bahasa Jepang. Sejalan dengan perkembangan teknologi, paradigma model pembelajaran pun sedikit demi sedikit berubah. Tujuan pembelajaran dan kebutuhan belajar disusun berdasarkan keinginan para pendidik bukan peserta didik. Sehingga motivasi untuk belajar menjadi hilang disebabkan oleh kenyataan bahwa peserta didik diharuskan belajar menurut apa yang harus dipelajari, bukan apa yang diinginkan oleh peserta didik. Padahal motivasi dari dalam diri sendiri adalah sangat dibutuhkan bagi seorang peserta didik untuk terus dan suka belajar.

Seiring pendapat Fenty (2011) bahwa perbedaan mendasar antara student centered learning (SCL) dengan teacher centered learning (TCL) terlihat jelas pada orientasinya. Orientasi strategi SCL lebih menekankan pada terjadinya kegiatan belajar oleh siswa, atau berorientasi pada pembelajaran (learning oriented), sedangkan strategi TCL lebih berorientasi pada konten (content oriented). Dengan kata lain, pada SCL mengajar tidak lagi dipahami sebagai proses untuk mentransfer informasi, akan

tetapi sebagai wahana untuk memfasilitasi terjadinya pembelajaran.

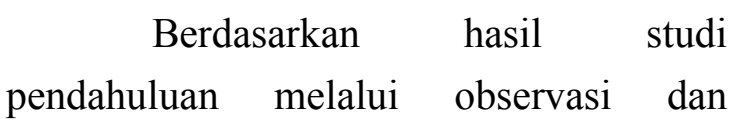
wawancara dengan siswa yang telah mengikuti mata kuliah Shokyu Dokkai / Hyouki bahwa setelah pembelajaran berakhir, mahasiswa hanya bisa mengingat huruf kanji pada saat itu saja, tetapi pada waktu berikutnya susah sekali mengingat cara baca huruf kanji yang sudah dipelajari bahkan mahasiswa tidak dapat membayangkan bagaimana cara menuliskannya. Ditambah pula, buku pegangan yang tidak menunjang.

Hal ini diperkuat dari hasil angket yang telah disebarkan kepada mahasiswa JPBJ FPBS UPI diketahui bahwa 80\% mahasiswa yang mengambil mata kuliah Shokyu Hyouki merasa kesulitan dalam mengingat makna kanji dan menghafal cara bacanya. Selama ini yang dipergunakan dalam pembelajaran Shokyu Hyouki hanya menggunakan buku utama dan buku tugas / lembar latihan. Dalam hasil tiap minggunya bagus, tetapi setiap ada tes keseluruhan mahasiswa merasa kesulitan (Meilia, 2012).

Oleh karena itu, untuk menyikapi permasalahan ini diperlukan metode pembelajaran yang lebih komunikatif dan materi yang menunjang dan lebih interaktif. Penulis menggunakan model pembelajaran yang berpusat pada mahasiswa (Student-Centered Learning) untuk membantu cara menghafal makna dan cara baca kanji secara mandiri disesuaikan kebutuhan. Media yang digunakan adalah $\mathrm{CD}$ interaktif mnemonik. Karena selama ini media yang digunakan hanya media power point dan buku saja.

Hal ini didasari dari penelitian sebelumnya bahwa hasil penelitian menunjukkan bahwa kemampuan responden dalam mengingat huruf kanji 
setelah menggunakan metode mnemonik teknik asosiasi belum bisa dikatakan meningkat,karena dari setiap responden menunjukkan hasil yang berbeda-beda yang dipengaruhi oleh faktor minat terhadap kanji dan gaya belajar masingmasing (Meilia, 2012).

Dalam blognya Santoso (2011) menuliskan bahwa pembelajaran StudentCentered Learning (selanjutnya disingkat SCL) menekankan pada minat, kebutuhan dan kemampuan individu, menjanjikan model belajar yang menggali motivasi intrinsik untuk membangun masyarakat yang suka dan selalu belajar. Model belajar ini sekaligus dapat mengembangkan kualitas sumber daya manusia yang dibutuhkan masyarakat seperti kreativitas, kepemimpinan, rasa percaya diri, kemandirian, kedisiplinan, kekritisan dalam berpikir, kemampuan berkomunikasi dan bekerja dalam tim, keahlian teknis, serta wawasan globaluntuk dapat selalu beradaptasi terhadap perubahan dan perkembangan (2006).

Paradigma pembelajaran SCL, dosen hanya sebagai fasilitator dan motivator dengan menyediakan beberapa strategi belajar yang memungkinkan mahasiswa (bersama dosen) memilih, menemukan dan menyusun pengetahuan serta cara mengembangkan ketrampilannya (method of inquiry and discovery). Pada SCL, ilmu pengetahuan tidak lagi dianggap statik tetapi dinamis dimana peserta didik secara aktif mengembangkan ketrampilan dan pengetahuannya artinya siswa secara aktif menerima pengetahuan tidak lagi pasif. Dengan demikian sangat mungkin nantinya siswa didik menjadi lebih pintar dari gurunya (tidak seperti film silat jaman dahulu dimana murid selalu kalah dari gurunya) apabila sang guru tidak aktif mengembangkan pengetahuannya.

SCL tidak melupakan peran dosen, dalam SCL dosen masih memiliki peran seperti (1) bertindak sebagai fasilitator dan motivator dalam proses pembelajaran; (2) mengkaji kompetensi matakuliah yang perlu dikuasai mahasiswa di akhir pembelajaran; (3) merancang strategi dan lingkungan pembelajaran dengan menyediakan berbagaipengalaman belajar yang diperlukan mahasiswa dalam rangka mencapai kompetensi yang dibebankan pada matakuliah yang diampu; (4) membantu mahasiswa mengakses informasi, menata dan memprosesnya untuk dimanfaatkan dalam memecahkan permasalahan nyata; (5) mengidentifikasi dan menentukan pola penilaian hasil belajar mahasiswa yang relevan dengan kompetensinya.

Sementara itu, peran yang harus dilakukan mahasiswa dalam pembelajaran SCL adalah (1) mengkaji kompetensi matakuliah yang dipaparkan dosen; (2) mengkaji strategi pembelajaran yang ditawarkan dosen; (3) membuat rencana pembelajaran untuk matakuliah yang diikutinya; (4) belajar secara aktif (dengan cara mendengar, membaca, menulis, diskusi, dan terlibat dalam pemecahan masalah serta lebih penting lagi terlibat dalam kegiatan berfikir; (5) tingkat tinggi seperti analisis, sintesis dan evaluasi), baik 
secara individu maupun berkelompok; (6) mengoptimalkan kemampuan dirinya.

Sedangkan Pada TCL, peran mahasiswa untuk aktif dalam perkuliahan menjadi terbatas. Perbaikan dari metode ini biasanya berupa diskusi tanya jawab tetapi dengan tetap mengedepankan peran dosen dalam perkuliahan. Dalam bahasa lain, ilmu pengetahuan dianggap sudah jadi dan dosen disini dikatakan melakukan transfer of knowledge. Tetapi yang akan dirubah dalam pembelajaran ini bukan dengan metode diskusi, tapi dengan mengubah media pembelajarannya dengan menggunakan CD interaktif.

Metode pembelajaran dengan pendekatan SCL merupakan metode pembelajaran yang menempatkan peserta didik sebagai pusat dari proses belajarmengajar. Metode pembelajaran dengan student centered menjadikan peserta didik aktif dan mandiri dalam proses belajarnya, mampu untuk menemukan sumber-sumber informasi untuk dapat menjawab pertanyaannya dan memiiki kemampuan dalam membangun serta mempresentasikan pengetahuannya berdasarkan kebutuhannya berdasarkan dengan sumber-sumber belajar, dalam batas-batas tertentu peserta didik mampu untuk memilih sendiri apa yang akan dipelajarinya (Pongtuluran dan Rahardjo, 1999).

Mnemonik merupakan teknik untuk memudahkan mengingat sesuatu. Secara lebih khusus, mnemonik berarti rumusan atau ungkapan untuk membantu mengingat-ingat sesuatu (Kamus Besar Bahasa Indonesia online). Dan menurut
Stine (1999), mnemonik adalah kemampuan otak untuk menghubungkan kata-kata, ide, dan khayalan. Berdasarkan definisi tersebut dapat dikatakan bahwa mnemonik adalah teknik untuk memudahkan mengingat sesuatu yang dilakukan dengan membuat rumusan atau ungkapan, atau menghubungkan kata, ide, dan khayalan. Dengan kata lain mnemonik berarti teknik untuk mendayagunakan daya ingat dengan cara-cara tertentu.

Instruksi mnemonik mengacu kepada instruksi atau strategi belajar yang terancang secara khusus untuk mengingatkan memori. Hal ini dimaksudkan untuk memodifikasi atau mengubah informasi yang bisa dipelajari dan bertujuan menghubungkan langsung dengan informasi dimana para pembelajar segera dapat mengetahuinya.

Mnemonik adalah teknik yang teruji ilmiah berdasarkan pengetahuan manusia tentang prinsip-prinsip memori. Terdapat hubungan kata untuk membantu mengingat bahan-bahan, metode pancang, teknik potong, asosiasi (cerita), asosiasi konyol dan penggunaan akronim dan akrostik. Teknik akronim dapat digunakan saat mempelajari warna-warna pelangi, yaitu mejikuhibiniu. Strategi mnemonik terkumpulkan dari berbagai artikel-artikel penelitian yang digunakan untuk mempelajari nama orang, bahasa asing, negara, ibukota, huruf-huruf alphabet dan pengejaan beberapa nama.

Adapun manfaat penggunaan teknik mnemonik, karena memudahkan mengingat, tentunya juga akan memudahkan belajar. Hambatan belajar 
akan hilang. Ini akan membangkitkan motivasi siswa untuk lebih giat belajar, sehingga akhirnya dapat mencapai hasil belajar yang optimal.

Jadi, capaian akhir penggunaan teknik mnemonik dalam pembelajaran adalah hasil belajar optimal dengan cara yang cepat dan mudah. Karena itu, teknik ini perlu diberikan kepada mahasiswa khususnya pembelajar kanji dasar.

Perkuliahan Shokyu Hyouki adalah mata kuliah menulis kanji dasar yang diajarkan pada semester 1, 2 dan 3 dengan bobot 2 sks (Tim Penyusun JPBJ). Mata kuliah ini sebagai mata kuliah penunjang kemampuan menulis dan membaca.

Sesuai dengan desain penelitian pada penelitian ini dilakukan 5 kali pertemuan baik di kelas eksperimen maupun kelas kontrol, dengan waktu pembelajaran setiap pertemuannya selama 100 menit. Pertemuan pertama dilakukan pre-test dan penjelasan perkuliahan dengan CD interaktif Mnemonik serta penginstalan program pada laptop masingmasing responden di kelas eksperimen dan pada kelas kontrol pun sama. Kemudian melakukan treatment pertama sampai empat. Dan diakhiri dengan mengadakan post-test dan mengisi angket yang berisi tentang pendapat responden mengenai pembelajaran yang dilakukan.

Semua langkah dilakukan sama pada kelas eksperimen (A) dan kelas kontrol (B), yang membedakan hanya media pembelajarannya saja. Pada kelas eksperimen (A) setiap pertemuan selalu ada latihan dan pengerjaan soal tapi semua dilakukan pada laptop masing-masing. Sedangkan pada kelas kontrol (B) latihan dan pengerjaan soal dilakukan di buku latihan (renshuuchou).

Media CD interaktif Mnemonik ini mempunyai menu「勉強」 atau 'belajar' yang berisi tentang materi setiap huruf kanji dengan cara baca kun-yomi dan onyomi, cara penulisan, lalu menu「練習」 atau latihan yang berisi latihan dari setiap huruf kanji dalam bentuk yomikata dan kakikata, menu「クイズ」 atau soal berisi tes dari materi yang diberikan dan menu 「ニーモニック」 atau mnemonik yang berisi asosiasi gambar dari pembentukan kanji. Konten $\mathrm{CD}$ ini sebagian besar mengambil referensi dari CD Omoshiroi Kanji (Marisa \& Riska, 2012). Ada banyak kesamaan $\mathrm{CD}$ interaktif ini dengan $\mathrm{CD}$ Omoshiroi Kanji, yang membedakannya adalah menu 'mnemonik', karena didalammnya berisikan asosiasi gambar yang dibuat sendiri untuk mempermudah mengingat makna dari sebuah kanji.

Alur pembelajaran pada kelas eksperimen (A) diawali dengan penjelasan materi apa yang kan dipelajari hari itu selama 15 menit, kemudian sisa waktu 85 menit untuk tahapan latihan dan pengerjaan soal diserahkan pada responden masing-masing. Langkah mana dulu yang akan dilakukan diberi kebebasan, tapi langkah terakhir harus mengerjakan 'kuis'.

Sesuai dengan pendapat Rogers (1983), SCL merupakan hasil dari transisis perpidahan kekuatan dalam proses pembelajaran, dari kekuatan dosen sebagai pakar menjadi kekuatan mahasiswa 
sebagai pembelajar. Dosen hanya sebagai fasilitator, mahasiswa dibiarkan untuk mengeksplor masing-masing.

Setiap model pembelajaran selalu ada nilai positif dan negatifnya. Menurut Geraldine O’Neil dan Tim McMahon (2005) bahwa titik perbedaan TCL dan SCL yaitu:

\begin{tabular}{|c|c|}
\hline $\begin{array}{c}\text { Teacher-Centered } \\
\text { Learning }(\boldsymbol{T C L})\end{array}$ & $\begin{array}{c}\text { Student-Centered } \\
\text { Learning }(\text { SCL })\end{array}$ \\
\hline Pilihan siswa & Pilihan siswa \\
tingkat rendah & tingkat tinggi \\
\hline Siswa pasif & Siswa aktif \\
\hline Kekuatan pada & Kekuatan pada \\
dasarnya ada di & dasarnya ada di \\
Guru & Siswa \\
\hline
\end{tabular}

Sejalan dengan pendapat Geraldine O’Neil dan Tim McMahon (2005) sama halnya dengan model pembelajaran Shokyu Hyouki dengan menggunakan media CD interaktif mnemonik pun ada kelebihan dan kelemahannya.

Dilihat dari kegiatan treatment, kelebihan dari pembelajaran kanji dengan menggunakan $\mathrm{CD}$ interaktif mnemonik adalah :

1) Mahasiswa bisa melakukan kegiatan sesuai keinginannya.

2) Media interaktif lebih hidup dan berwarna, sehingga membangkitkan motivasi mahasiswa.

3) Apabila ada mahasiswa yang menangkap memori agak lama, dapat dilakukan secara berulang-ulang tanpa aturan.

4) Selain di kelas, belajar bisa dilakukan dimana saja untuk fukushuu (mengulang pelajaran) ataupun youshuu (mempersiapkan pelajaran).
Sedangkan kelemahan dari pembelajaran ini adalah :

1) Media ini bergantung pada fasilitas yang ada di setiap tempat pembelajaran, yaitu harus tersedia lab komputer ataupun perangkat laptop pribadi.

2) Pengajar tidak mengetahui secara langsung kesulitan mahasiswa apabila ada masalah.

3) Apabila terjadi pemadaman listrik akan menghambat model pembelajaran ini.

Dilatarbelakangi oleh hasil penelitian tersebut, dalam penelitian ini, peneliti mengubah media pembelajaran yang digunakan yaitu $\mathrm{CD}$ interaktif. Hal ini disesuaikan dengan minat mahasiswa saat ini lebih menyukai gaya belajar yang praktis dan bisa dilakukan kapan saja dan atas dasar bahwa pembelajaran harus dilakukan dengan menarik tanpa paksaan.

\section{METODE}

Pada penelitian ini penulis menggunakan metode eksperimen sungguhan / murni (true experimental). Metode eksperimen sungguhan merupakan metode penelitian yang memungkinkan peneliti memanipulasi variabel dan meneliti akibat-akibatnya (Cresswel, 2010).

Penelitian ini adalah penelitian lanjutan dari penelitian sebelumnya (Meilia, 2012) yaitu tahap keempat dari rangkaian penelitian Research and Development bagian pengembangannya (Development).

Subyek dalam penelitian ini menggunakan 2 buah kelas yang diambil 
dari mahasiswa tingkat 2 semester 3 Jurusan Pendidikan Bahasa Jepang FPBS UPI. Satu kelas diambil dari kelas A sebagai kelas eksperimen, yaitu kelas yang menggunakan pembelajaran $\mathrm{CD}$ interaktif mnemonik. Kemudian satu kelas lagi dari kelas B sebagai kelas kontrol, yaitu kelas yang menggunakan media buku ajar seperti biasa.

Adapun yang menjadi sampel dalam penelitian ini adalah dari kelas A 15 orang sebagai kelas eksperimen dan 15 orang dari kelas B sebagai kelas kontrol. Setiap kelompok terdiri dari tingkat kecerdasan yang heterogen.

Untuk mendapatkan informasi yang lebih mendalam (Alwasilah, 2005 : 154), peneliti melakukan interviu pada seluruh anggota sampel mahasiswa dan seorang pengajar perkuliahan Shokyu Dokkai / Hyouki di Jurusan Pendidikan Bahasa Jepang FPBS UPI sebagai pilot study.
Disain penelitian eksperimen yang digunakan berbentuk pre-test - eksperimen - post test. Dapat digambarkan sebagai berikut :

$\mathbf{O}_{1}-\mathbf{X}_{1}-\mathbf{X}_{2}-\mathbf{X}_{3}-\mathbf{X}_{4}-\mathbf{X}_{5}-\mathbf{O}_{2}$

\section{HASIL DAN PEMBAHASAN}

\section{Keefektifan Media CD Interaktif Mnemonik}

Dari hasil kegiatan yang dilakukan di kelas eksperimen (A) dan kelas kontrol (B) dapat diukur keberhasilan pembelajaran menggunakan media CD interaktif mnemonik dengan media buku ajar. Kemampuan responden dalam mengingat makna kanji diukur dari nilai pre-test dan post-test. Nilai rata-rata pre-test kelas A adalah 77 dan nilai ratarata post-test adalah 85. Sedangkan pada kelas B pre-test kelas A adalah 89 dan nilai rata-rata post-test adalah 78. Apabila digambarkan dalam grafik batangan sebagai berikut.

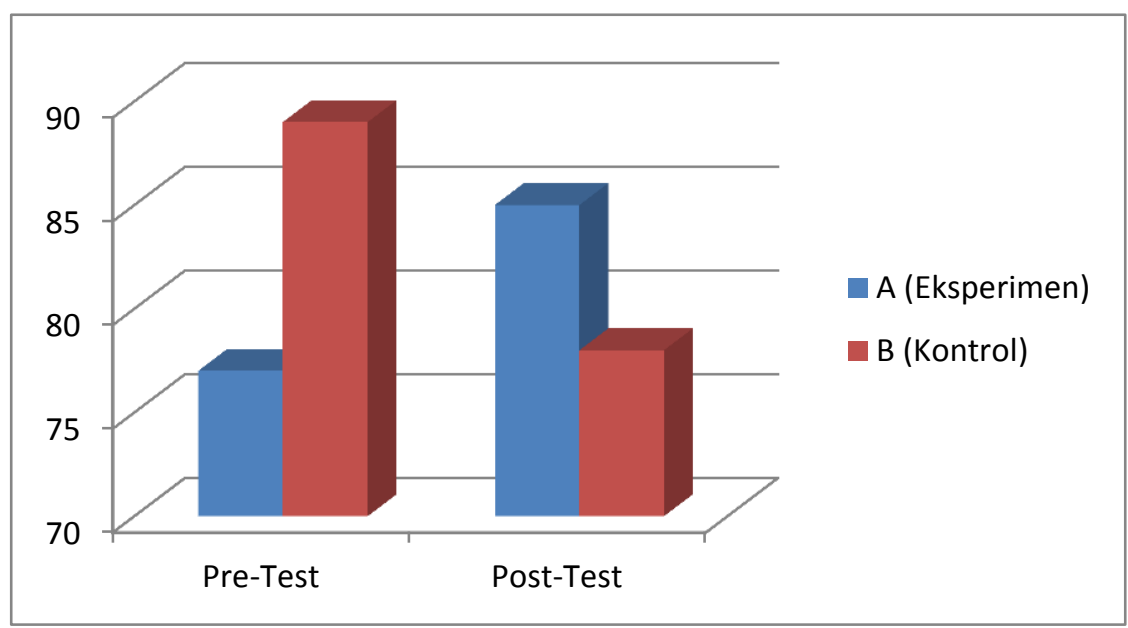

Dapat disimpulkan bahwa secara keseluruhan kemampuan kelas A mengalami peningkatan dalam pemahaman mengingat makna kanji dengan menggunakan media CD interaktif mnemonik. Berbanding terbalik dengan kelas B mengalami penurunan nilai. Dengan kata lain pembelajaran kanji dasar dengan menggunakan media CD interaktif mnemonik lebih efektif dalam mengingat 
makna kanji.

Hasil ini diperkuat dengan hasil angket dan wawancara yang telah dihimpun bahwa penurunan nilai pada kelas kontol disebabkan banyak faktor diantaranya materi kanji yang bertambah sulit sehingga sulit untuk dihafal dan media buku ajar serta buku latihan tidak sangat monoton. Sedangkan peningkatan nilai pada kelas eksperimen disebabkan karena media yang digunakan cukup interaktif, selain bisa diulang-ulang, media CD dapat digunakan kapan saja dan dimana saja.

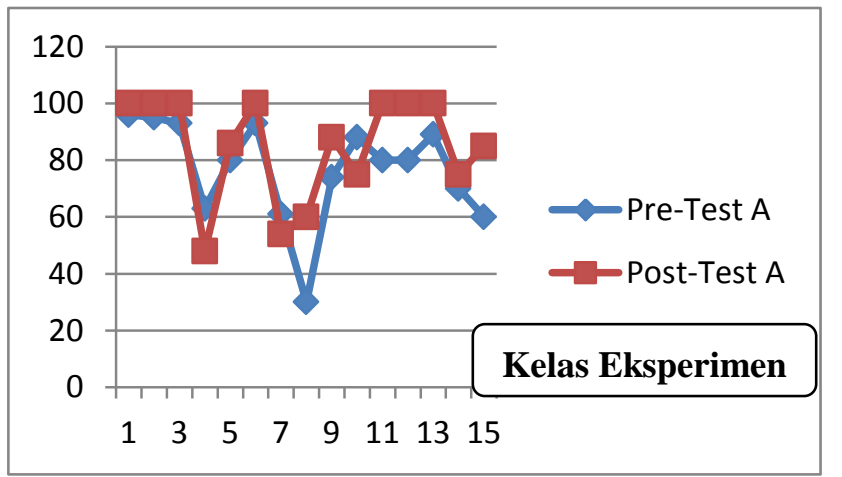

2. Respon Mahasiswa terhadap Model Pembelajaran dengan Media CD Interaktif Mnemonik

Hasil wawancara dan angket yang dihimpun dari responden menunjukkan bahwa responden pada kelas eksperimen seluruhnya menyukai pembelajaran dengan menggunakan media $\mathrm{CD}$ interaktif mnemonik. Terutama pada saat menghafalkan makna kanji sangat terbantu oleh asosiasi gambar pembentuk kanji (mnemonik). Ketika responden melakukan tes, memorinya langsung ke asosiasi gambar tersebut, sehingga mempermudah pada saat menuliskan huruf
Apabila melihat kemampuan masing-masing responden, sebagian besar responden kelas A mengalami peningkatan, sedangkan beberapa yang mengalami penurunan termasuk pada mahasiswa yang memiliki latar belakang tidak menyukai kanji dan dari kelompok rendah. Sedangkan pada kelas B hamper semua responden mengalami penurunan nilai. Hal ini bukan lagi dikarenakan latar belakang responden menyukai kanji atau tidak, tetapi lebih dari gaya belajar yang dilakukan selama treatment. Dapat dilihat dari grafik batang sebagai berikut,

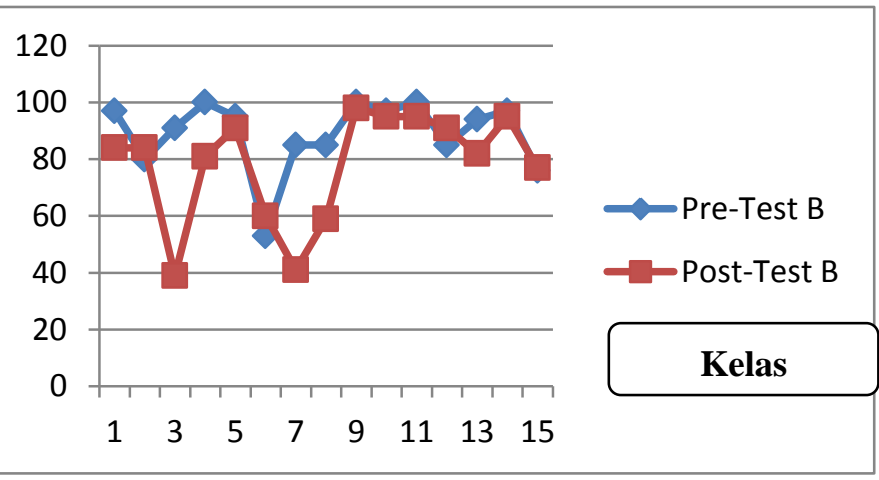

kanji. Tetapi kesulitannya ada beberapa asosiasi gambar yang tidak bisa dengan mudah untuk dimengerti. Hal ini disebabkan oleh pemahaman dan penafsiran setiap orang berbeda-beda.

\section{SIMPULAN DAN SARAN}

Berdasarkan hasil analisis data di atas dapat disimpulkan bahwa (1) Pembelajaran kanji dasar dengan menggunakan media $\mathrm{CD}$ interaktif mnemonik sangat efektif untuk menghafalkan makna kanji dan mempermudah dalam pengerjaan soal-soal tes; (2) Penerapan model pembelajaran 
kanji dengan CD interaktif mnemonik sesuai dengan prinsip SCL yaitu, melalui sistem Student-Centered Learning yang menghargai keunikan tiap individu dari tiap peserta didik, baik dalam minat, bakat, pendapat serta cara dalam gaya belajarnya, tiap peserta didik disiapkan untuk dapat menghargai diri sendiri, orang lain serta perbedaan, menjadi bagian dari masyarakat yang demokratis dan berwawasan global; (3) Dosen yang menerapkan SCL harus memiliki karakteristik sebagai berikut, mengakui dan menghargai keunikan masing-masing mahasiswa dengan cara mengakomodasi pemikiran mahasiswa, gaya belajarnya, tingkat perkembangannya, kemampuan, bakat, persepsi diri, serta kebutuhan akademis dan non akademis mahasiswa. Serta menciptakan iklim pembelajaran yang positif dengan cara memberikan kesempatan pada mahasiswa untuk berbicara dengannya secara personal, memahami siswa dengan sebaik-baiknya, menciptakan lingkungan yang nyaman dan menstimulasi bagi siswa, memberikan dukungan pada siswa, mengakui dan menghargai siswa.; (4) Setiap dosen harus selalu mengingatkan pada para mahasiswa diminta untuk mengevaluasi pekerjaannya. Evaluasi diri diperlukan untuk menilai kualitas pekerjaan yang telah dilakukan oleh para mahasiswa, semua mahasiswa harus mengetahui bahwa hasil pekerjaannya akan dievaluasi, berdasarkan hasil eveluasi itulah mahasiswa tahu bagaimana kualitas pekerjaannya dapat ditingkatkan serta dapat mengulangi prosesnya sampai kualitas terbaik dapat dicapai; (5) Dari hasil wawancara dan angket yang dirangkum, seluruh responden menyukai model pembelajaran seperti ini dan sebagian besar responden berpendapat bahwa dengan adanya media pembelajarn seperti ini sangat membantu mahasiswa dalam mengerjakan soal khususnya dalam menuliskan kanji; (6) Kelemahan dari pembelajaran dengan menggunakan media CD interaktif adalah bergantung pada fasilitas listrik dan ketersediaan perangkat komputer / laptop; (7) Rekomendasi untuk penelitian selanjutnya adalah agar dapat dilanjutkan untuk model pembelajaran kanji tingkat menengah ke atas, dan mencari solusi dari permasalahan bagaimana cara yang efektif untuk mengingat cara baca kanji baik kun-yomi maupun on-yomi.

\section{UCAPAN TERIMA KASIH}

Peneliti mengucapkan terima kasih kepada redaksi jurnal bahasa \& sastra yang telah memublikasikan artikel hasil penelitian ini.

\section{PUSTAKA RUJUKAN}

Alwasilah, C. 2005. Pokoknya Menulis. Bandung : Kiblat Utama.

Creswell, J, W.2010. Research Design (terjemahan). Yogyakarta : Pustaka Pelajar.

Marisa \& Riska. 2012. Upaya Menginngat Kanji dengan Mudah Melalui Media 'Omoshiroi Kanji'. Skripsi di Jurusan Bahasa Jepang UNIKOM : tidak diterbitkan.

Meilia, L. 2012. Upaya Mengingat Makna 
Kanji Melalui Metode Mnemonik dengan Teknik Asosiasi dalam Pembelajaran Kanji Dasar (Shokyu Hyouki). Hibah Pembinaan Dosen Muda UPI : tidak diterbitkan.

Pongtuluran, A dan Rahardjo, A.I. 1999.

Student-Centered Learning: The Urgency and Possibilities. Seminar Sehari : Innovative Approaches in Higher Education, Universitas Kristen Petra, Surabaya, 28 Agustus. 1999.

Rogers, C. 1983. As a teacher, can I be myself? In Freedom to learn for the 80s. Ohio: Charles E. Merrill Publishing Company.

Stine, J.M. 1999. Double Your Brain Power. Amerika : Amazon.

Tim Penyusun JPBJ. 2011. Shokyu Hyouki

2. Modul Perkuliahan Jurusan

Pendidikan Bahasa Jepang FPBS

UPI : tidak diterbitkan.

http://uripsantoso.files.wordpress.com/201

1/06/scl1.pdf

http://bintangku.mywapblog.com/perbedaa

n-teacher-centered-learning-tcl.xhtml http://www.aishe.org/readings/2005-

1/oneill-mcmahon-

Tues_19th_Oct_SCL.html

http://fairuzelsaid.wordpress.com/2010/08/

28/pendidikan-konsep-scl-student-

centered-learning/

http://kbbi.web.id.

http://eprints.uny.ac.id/9793/2/BAB\%202

$\% 20-\% 2008111241002 . p d f$ 